\title{
The Effect of Financial Compensation and Work Stress on the Job Satisfaction of Go- Jek (Go-Ride) Driver Partners in Bandung Area in the Covid-19 Pandemic
}

\section{${ }^{1 *}$ Didi Tarmidi, ${ }^{2}$ Rismauli Simbolon, ${ }^{3}$ Wisnu Astawa Putra, ${ }^{4}$ Andi Rahman Sulaeman and ${ }^{5}$ Mochamad Farhan}

Business and Economy Faculty, Widyatama University, Indonesia

1*didi.tarmidi@widyatama.ac.id,_2rismauli.simbolon@widyatama.ac.id,_3astawa.wisnu@widyatama.ac.id,

4andi.rahman@widyatma.ac.id, ${ }^{5}$ mochamad.farhan@widyatama.ac.id

Article History: Received:11 January 2021; Accepted: 27 February 2021; Published online: 5 April 2021

\begin{abstract}
This study aims to determine the effect of Financial Compensation and Work Stress on The Work Satisfaction of the Go-jek Driver Partners (go-ride) Bandung Area in the Covid-19 Pandemic both partially and simultaneously. The research method used is the descriptive and verificative method with data collection using field research and literature research. The population in this study is the driver-partner of PT GO-JEK Indonesia Central Bandung Region. The sample used as many as 115 respondents. Based on the results of the analysis concluded that: 1) there is a significant influence together (simultaneously) of financial compensation and work stress on the job satisfaction of GO-JEK driver-partners. 2) Financial compensation affects the variable Job satisfaction of GO-JEK driver-partners. If the financial compensation is getting better, then the job satisfaction of GO-JEK driver-partners will increase, as well as if the financial compensation gets worse than the job satisfaction of GO-JEK driver-partners will decrease. 3) Work stress has a significant and negative effect on the variable Work satisfaction of GO-JEK driver-partners. If work stress increases, it will decrease the job satisfaction of GO-JEK driver-partners. Likewise, if work stress decreases it will increase the job satisfaction of GO-JEK driver-partners.
\end{abstract}

Keywords: Financial compensation; work stress; job satisfaction

\section{Introduction}

Human resources in a corporate organization is an inseparable entity. The organization of the company can run following the expectations if there are human beings who have the same goal that is to make the organization where he works and make a living it can experience an increase in profits and development every year.

Congestion and unreliable public transportation are common problems in several major cities in Indonesia, and motorcycle taxis are one solution. However, often consumers are made kapok with tariffs that are not standard. So people prefer to use a mode of transportation whose price may differ thinly, or bring their vehicle.

All changed after popping up service online, be it that can be ordered by phone, application, or other means. Users are also spoilt for choice with transparent rates that are generally calculated per kilometer. In Indonesia, it looks like GO-JEK was the first to present an online transportation application before competitors sprung up. Changing the way you book your vehicle is quick, easy, and convenient. With just a gadget, the cost can also be said to be measurable and affordable.

The working relationship of PT. GO-JEK Indonesia with drivers is a partnership. Go-JEK partnership system makes a great interest for motorcycle and car users, until now for Bandung there are more than 15000 GO-RIDE partners and 2000 GO-CAR Partners (Source PT. GO-JEK INDONESIA). Users of the GO-JEK Application in Bandung city are increasing, this is marked by the increasing number of GO-JEK app downloaders on the play store.

According to Mondy (2016), Compensation is the entirety of all gifts given to employees in return for their services. The provision of direct financial compensation consists of payments earned by employees in the form of salaries, wages, bonuses, and commissions.

According to Robbin (2015), stress is a dynamic condition in which an individual is faced with opportunities, limitations, or demands following the expectations of the results he wants to achieve in important and uncertain conditions.

When the Covid 19 pandemic hit the country directly changed the social and economic structure not unless gojek driver partners were affected, based on the description we were interested to examine the influence between employee job satisfaction variables, financial compensation, and work stress. 


\section{Theoretical Studies}

\subsection{Financial compensation}

Financial compensation according to Rivai and Sagala (2016) is a reward given by the company to employees in the form of money.

\subsection{Work stress}

According to Anoraga (2014), work stress is a form of one's response, both physical and mental to a change in his environment that is perceived to be disruptive and results in him being threatened.

\subsection{Job satisfaction}

According to Rivai (2015), job satisfaction is an evaluation that describes a person for feeling happy or unhappy, satisfied or dissatisfied at work. According to Rivai (2015) states that according to the Job Descriptive Index (JDI) the cause of satisfaction factor is 1) working in the right place, 2) the appropriate payment, 3) Organization and management, 4) supervise on the right job, and 5) the person who is in the right job.

\subsection{Research conceptual framework and hypothesis development}

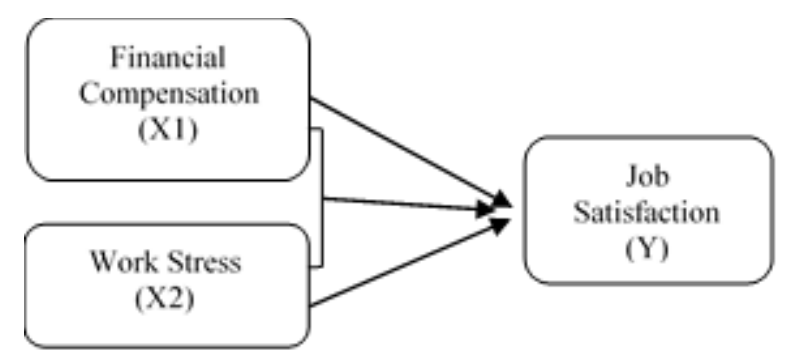

In line with the frame of thought, in conducting this study the author formulated the hypothesis of submission as follows:

H1: There is an effect of financial compensation on job satisfaction

H2: There is an Effect of Work Stress on Job Satisfaction

H3: There is an effect of financial compensation and work stress on job satisfaction

\section{Methods}

The method used by the authors is the descriptive and verificative research method. To find out the effect of financial compensation and work stress on job satisfaction. The research data obtained is processed and analyzed quantitatively. A quantitative approach is a research method based on the philosophy of positivism, used to research a particular population or sample (Sugiyono, 2018). With statistics test, it can be known the Effect of Financial Compensation and Work Stress on Job Satisfaction.

\subsection{Population and research samples}

\subsubsection{Population}

According to Sugiyono (2017), the definition of population is a generalized area consisting of objects or subjects of certain characteristics set by researchers to be studied and then drawn conclusions. So in this study the population is the driver partner of PT GO-JEK Indonesia Central Bandung Region.

\subsubsection{Samples}

According to Sugiyono (2017), samples are part of the number and characteristics that the population has. This sampling must be done in such a way that the sample can function or can describe the actual state of the population, therefore the sample that must be taken from the population must be truly representative (representative). The minimum number of samples used in this study was 115 respondents. 


\subsection{Data collection techniques}

Data collection techniques are ways that are done for. obtain the necessary data and information in the research (Sugiyono, 2017). The data collection techniques performed by the authors in this study are using field research and literature research.

\section{Results and Discussion}

The results of data obtained from 100 respondents showed the results obtained are as follows:

Table 1. Questionnaire return rate

\begin{tabular}{cc}
\hline Number of questionnaires distributed & 115 \\
\hline Number of questionnaires that did not return & 0 \\
\hline Number of questionnaires returned & 115 \\
\hline Number of questionnaires analyzed & 115 \\
\hline Questionnaire return rate $115 / 115 X 100 \%$ & $100 \%$ \\
\hline
\end{tabular}

\subsection{Validity test}

The results of the Validity Test of this study are as follows:

Table 2. Validity test X1

\begin{tabular}{cccc}
\hline Item & $\mathrm{r}_{\text {count }}$ & $\mathrm{r}_{\text {table }}$ & Result \\
\hline 1 & 0.670 & 0.176 & valid \\
\hline 2 & 0.712 & 0.176 & valid \\
\hline 3 & 0.414 & 0.176 & valid \\
\hline 4 & 0.711 & 0.176 & valid \\
\hline 5 & 0.728 & 0.176 & valid \\
\hline 6 & 0.646 & 0.176 & valid \\
\hline 7 & 0.526 & 0.176 & valid \\
\hline 8 & 0.509 & 0.176 & valid \\
\hline 9 & 0.531 & 0.176 & valid
\end{tabular}

Table 3. Validity test $\mathrm{X} 2$

\begin{tabular}{cccc}
\hline Item & $\mathrm{r}_{\text {count }}$ & $\mathrm{r}_{\text {table }}$ & Result \\
\hline 1 & 0.824 & 0.176 & valid \\
\hline 2 & 0.811 & 0.176 & valid \\
\hline 3 & 0.797 & 0.176 & valid \\
\hline 4 & 0.840 & 0.176 & valid \\
\hline 5 & 0.797 & 0.176 & valid \\
\hline 6 & 0.784 & 0.176 & valid \\
\hline 7 & 0.810 & 0.176 & valid \\
\hline 8 & 0.773 & 0.176 & valid \\
\hline 9 & 0.774 & 0.176 & valid \\
\hline 10 & 0.787 & 0.176 & valid \\
\hline 11 & 0.698 & 0.176 & valid \\
\hline
\end{tabular}

Table 4. Validity test $\mathrm{Y}$

\begin{tabular}{cccc}
\hline Item & $\mathrm{r}_{\text {count }}$ & $\mathrm{r}_{\text {table }}$ & Result \\
\hline 1 & 0.369 & 0.176 & valid \\
\hline 2 & 0.308 & 0.176 & valid \\
\hline 3 & 0.665 & 0.176 & valid \\
\hline 4 & 0.645 & 0.176 & valid \\
\hline 5 & 0.442 & 0.176 & valid \\
\hline 6 & 0.585 & 0.176 & valid \\
\hline 7 & 0.342 & 0.176 & valid \\
\hline 8 & 0.476 & 0.176 & valid \\
\hline 9 & 0.462 & 0.176 & valid \\
\hline
\end{tabular}


1*Didi Tarmidi, ${ }^{2}$ Rismauli Simbolon, ${ }^{3}$ Wisnu Astawa Putra, ${ }^{4}$ Andi Rahman Sulaeman and ${ }^{5}$ Mochamad Farhan

\begin{tabular}{cccc}
\hline 10 & 0.525 & 0.176 & valid \\
\hline 11 & 0.482 & 0.176 & valid \\
\hline 12 & 0.185 & 0.176 & valid \\
\hline 13 & 0.474 & 0.176 & valid \\
\hline 14 & 0.321 & 0.176 & valid \\
\hline 15 & 0.576 & 0.176 & valid \\
\hline 16 & 0.553 & 0.176 & valid \\
\hline 17 & 0.711 & 0.176 & valid \\
\hline 18 & 0.394 & 0.176 & valid \\
\hline 19 & 0.406 & 0.176 & valid \\
\hline 20 & 0.538 & 0.176 & valid \\
\hline 21 & 0.774 & 0.176 & valid \\
\hline 22 & 0.721 & 0.176 & valid \\
\hline 23 & 0.634 & 0.176 & valid \\
\hline
\end{tabular}

Validity test is used $\mathrm{N}=100$, so it is known $\mathrm{Df}=\mathrm{N}-2$, then $\mathrm{r}$ table of 0.1966 as the limit of the value of the statement is considered valid. For all variables can be declared valid, because it has passed the minimum according to $r$ table.

\subsection{Reliability test}

Reliability tests are conducted to show the extent to which a measurement result is relatively consistent when measuring against the same aspect on the same measuring instrument. A set of questions to measure a variable is said to be reliable and successfully measures the variable we measure if its reliable coefficient is greater than or equal to $0.6(>0.60)$.

Table 5. Reliability test

\begin{tabular}{cccc}
\hline Variable & Cronbach's Alpha & Cronbach's Alpha Based on Standardized Items & N of Items \\
\hline $\mathrm{X}_{1}$ & 0.869 & 0.870 & 9 \\
\hline $\mathrm{X}_{2}$ & 0.953 & 0.955 & 11 \\
\hline
\end{tabular}

For all variables obtained by Cronbach's Alpha $>0.60$, the questionnaire for this variable is declared reliable.

\subsection{Correlation coefficient}

Table 6. Correlation coefficient and coefficient of determination of financial compensation and work stress to work satisfaction of GO-JEK driver-partners

Coefficients $^{\mathbf{a}}$

\begin{tabular}{ccccc}
\hline Model & R & R Square & Adjusted R Square & Std. Error of the Estimate \\
\hline 1 & $.616^{\mathrm{a}}$ & .380 & .369 & 8.11815 \\
\hline
\end{tabular}

Based on Table 6, the calculation result of the correlation coefficient $(\mathrm{R})$ is 0.616 . The value is between the value of $0.60-0.799$ meaning Financial compensation (X1) and Work stress (X2) have a strong relationship with the job satisfaction of GO-JEK driver-partners (Variable Y).

\subsection{Coefficient of determination}

From Table 6, it is known that the coefficient of determination is 0.380 or $38.0 \%$, meaning that the variables financial compensation (X1) and Work stress (X2) have an influence on the job satisfaction of GO-JEK driverpartners (Variable $\mathrm{Y}$ ) of $38.0 \%$ and the remaining $61.0 \%$ influenced by other factors.

\subsection{Partial hypothesis testing}

First Hypothesis

$\mathrm{H}_{0}: \rho \leq 0$, means that there is no effect between financial compensation on the job satisfaction of GO-JEK driver partners.

$\mathrm{H}_{1}: \rho>0$, means that there is an effect of financial compensation on the job satisfaction of GO-JEK driverpartners. 
Table 7. Financial compensation variable hypothesis test results (X1) to the job satisfaction of GO-JEK driverpartners

\section{Coefficients $^{\mathrm{a}}$}

\begin{tabular}{llcl}
\hline & Model & $\mathrm{t}$ & Sig. \\
\hline \multirow{2}{*}{1} & $($ Constant $)$ & 8.206 & .000 \\
\cline { 2 - 4 } & Compensation & 8.321 & .000 \\
\hline
\end{tabular}

From Table 7 , it can be concluded that the value of things $(8,321)>$ ttable $(1,658)$ and significance value of $0.000<0.05$ means, Ho is rejected. Thus the variable Financial compensation (X1) affects the variable Job satisfaction of GO-JEK driver-partners (Variable Y). If the financial compensation is getting better, then the job satisfaction of GO-JEK driver-partners will increase, as well as if the financial compensation gets worse than the job satisfaction of GO-JEK driver-partners will decrease.

Table 8. Results of work stress variable hypothesis test (X2) on work satisfaction of GO-JEK driver partners Coefficients $^{\mathrm{a}}$

\begin{tabular}{llcl}
\hline & Model & $\mathrm{t}$ & Sig. \\
\hline \multirow{2}{*}{1} & $($ Constant $)$ & 4.551 & .000 \\
\cline { 2 - 4 } & Job Stress & 8.244 & .000 \\
\hline
\end{tabular}

From Table 8 , it can be concluded that the value tcount $(8,244)>$ ttable $(1,658)$ and significance value 0.000 $<0.05$ means, Ho is rejected. Thus the variable Work stress (X2) affects the variable Job satisfaction of go-jek driver-partners (Variable Y). If work stress increases, it will decrease the job satisfaction of GO-JEK driverpartners. Likewise, if work stress decreases it will increase the job satisfaction of GO-JEK driver-partners.

\subsection{Simultaneous hypothesis testing (F test)}

To be able to know the effect of financial compensation and work stress on the work satisfaction of GO-JEK driver-partners simultaneously, it is necessary to test hypotheses where the results can be obtained in the following table:

Table 9. Simultaneous hypothesis testing $(\mathbf{F}$ test $)$

ANOVA $^{\text {b }}$

\begin{tabular}{|c|c|c|c|}
\hline Model & Sum of Squares df & Mean Square & Sig. \\
\hline 1Regression & 4525.098 & 2262.549 & $34.331 .000^{\circ}$ \\
\hline Residual & 7381.284 & 65.904 & \\
\hline Total & $11906.383 \quad 114$ & & \\
\hline
\end{tabular}

\subsection{Formulating the zero hypothesis}

$\mathrm{H}_{0}: \beta_{1}=\beta_{2}=0$, means that there is no simultaneous effect of Financial compensation (Variable X1) and Work stress (Variable X2) on the job satisfaction of GO-JEK driver-partners (Variable Y).

$\mathrm{H}_{1}: \beta_{1 \neq} \beta_{2 \neq} 0$, means that there is simultaneous effect of Financial compensation (Variable X1) and Work stress (Variable X2) on the job satisfaction of GO-JEK driver-partners (Variable Y).

\subsection{Specify $F$ count}

From Table 9, it can be seen that the value of Fcount $(34,331)>$ Ftable $(3,232)$ then $\mathrm{H} 0$ is rejected and $\mathrm{H} 1$ is received which means that there is a significant influence together (simultaneously) of financial compensation (Variable X1) and Work Stress (Variable X2) on the work satisfaction of GO-JEK driver-partners (Variable Y).

\section{Results and Discussion}

Based on the results of the determination test in table 6 it is known that the coefficient of determination is 0.380 or $38.0 \%$, meaning that the variables Financial compensation (X1) and Work stress (X2) influence the job satisfaction of GO-JEK driver-partners (Variable Y) of 38.0\% and the remaining $61.0 \%$ influenced by other factors. 
${ }^{1 *}$ Didi Tarmidi, ${ }^{2}$ Rismauli Simbolon, ${ }^{3}$ Wisnu Astawa Putra, ${ }^{4}$ Andi Rahman Sulaeman and ${ }^{5}$ Mochamad

Farhan $(1,658)$.

Based on the results of the first hypothesis test on financial compensation (X1), tcount value $(8,321)>$ ttable

In the results of the second hypothesis test against work stress (X2), tcount value $(8,244)>$ ttable $(1,658)$ and significance value of $0.000<0.05$ means, Ho was rejected and $\mathrm{H} 1$ was accepted. Thus the variable Financial compensation (X1) Work stress (X2) affects the variable Job satisfaction of go-jek driver-partners (Variable Y).

Then in the last part through the hypothesis test simultaneously obtained the value of Fcount $(34,331)>$ Ftable $(3,232)$ then $\mathrm{H} 0$ is rejected and $\mathrm{H} 1$ is accepted which means there is a significant influence together (simultaneously) of financial compensation (Variable X1) and Work Stress (Variable X2) on the job satisfaction of GO-JEK driver-partners (Variable Y).

\section{Conclusion}

Based on the results of the research and discussion, it can be concluded as follows:

1. Based on the results of the study shows that there is a significant influence together (simultaneous) of financial compensation and work stress on the job satisfaction of GO-JEK driver-partners.

2. Financial compensation affects the variable Work satisfaction of GO-JEK driver-partners. If the financial compensation is getting better, then the job satisfaction of GO-JEK driver-partners will increase, as well as if the financial compensation gets worse than the job satisfaction of GO-JEK driver-partners will decrease.

3. Work stress has a significant and negative effect on the variable Work satisfaction of GO-JEK driverpartners. If work stress increases, it will decrease the job satisfaction of GO-JEK driver-partners. Likewise, if work stress decreases it will increase the job satisfaction of GO-JEK driver-partners.

\section{References}

1. Abdus Salam, 2014, Manajemen Personalia (Manajemen Sumber Daya Manusia), Ghalia, Jakarta.

2. Agus Pande Saeka, I Putu and I Wayan Suana. (2016). Pengaruh Kepuasan Kerja, Komitmen Organisasional Dan Stres Kerja Terhadap Turnover Intention Karyawan PT. Indonusa Algaemas Prima Bali, E-Jurnal Manajemen Unud, 5(6): 3736-3760.

3. Anoraga, Panji. (2014). Psikologi Kerja. Jakarta: Rineka Cipta.

4. Ardinal Djalil, Wiara Sanchia Devi (2020) Pengaruh Kompensasi Finansial Dan Stres Kerja Terhadap Kepuasan Kerja Karyawan (Studi pada Karyawan bagian Produksi PT Daya Anugrah Mandiri), EKONAM: Jurnal Ekonomi, Vol. 02 No. 2, 86-94.

5. Axel R. Runtulalo, William A. Areros, Sofia A.P. Sambul (2020) Kompensasi Finansial dan Stres Kerja Terhadap Kepuasan Kerja Mitra Driver PT. Go-Jek Indonesia (Go-Ride) Productivity, Vol. 1 No. 4.

6. Dan Gunnardi Lebang (2017) Analisis Pengaruh Motivasi, Lingkungan Kerja, Kompetensi dan Kompensasi Terhadap Kepuasan Kerja dan Kinerja pada Driver GO-JEK, Jurnal Ma. IBS.

7. Danang, Sunyoto, (2016), Perilaku Organisasi, Bandung: Penerbit Yrama Widya.

8. Dessler, Gary. (2015). Manajemen Sumber Daya Manusia. Jakarta: Salemba Empat.

9. Ghozali, I (2016), Aplikasi Analisis Multivariate Dengan SPSS. Badan Penerbit Universitas Diponegoro, Semarang.

10. Handoko, T. Hani. (2015). Manajemen Personalia dan Sumber Daya Manusia. BPFE, Yogyakarta.

11. Hasibuan, S.P (2016), Manajemen Sumber Daya Manusia. Bumi Aksara, Jakarta.

12. Imam Syaiful Wicaksono (2019) Pengaruh Kompensasi Dan Fleksibilitas Kerja Driver Gojek Terhadap Kinerja Dengan Kepuasan Kerja Sebagai Variabel Intervening, Universitas Islam Indonesia Yogyakarta.

13. Iqbal Setiawan (2018) Pengaruh Kompensasi Finansial Dan Stres Kerja Terhadap Kepuasan Kerja Mitra Driver Go-Jek (Go-Ride) Di Daerah Istimewa Yogyakarta, Skripsi, Universitas Negeri Yogyakarta.

14. Irwan Lukiyanto (2019) Pengaruh Kompensasi Finansial Dan Stres Kerja Terhadap Kepuasan Kerja Karyawan, Jurnal Ilmu Manajemen Volume 2 Nomor 1.

15. Khoirunnisa Isnaini (2015) pengaruh lingkungan kerja dan stress kerja terhadap kinerja karyawan Pada PT. Putra Nugraha Sentosa Mojosongo), Universitas Muhammadiyah Surakarta.

16. Luther Gulick, (2015), Educational Administration. New York, McGraw-Hill.

17. Mangkunegara, A.P (2016), Manajemen Sumber Daya Manusia, Bandung, Penerbit: Remaja Rosdakarya.

18. Masri. S.R. and Kuncoro. (2015). Metode Penelitian Kuantitatif. Bandung: Alfabeta.

19. Mersa Candra Pratama (2016), Pengaruh Lingkungan Kerja Dan Stres Kerja Terhadap Kinerja Pegawai Pada Badan Perencanaan Pembangunan Daerah Provinsi Lampung. Skripsi, Universitas Lampung. 
20. Mita Desy Yani, Endang Dwiyanti (2016) Hubungan Kompensasi Finansial Dan Stres Kerja Dengan Kinerja Karyawan Pt. Dok Dan Perkapalan Surabaya (Persero). Indonesian Journal of Occupational Safety and Health, 5(2), 163-172.

21. Mochamad Syafii, and Tety Lindawati (2016) pengaruh lingkungan kerja dan stress kerja terhadap kinerja karyawan di PERUM Perhutani Kesatuan Bisnis Mandiri Industri Kayu Gresik, GEMA EKONOMI (Jurnal Fakultas Ekonomi), 5(2), 133-146.

22. Mondy, R.W., and Martocchio, J.J. (2016), Human Resource Management. Harlow: Pearson Education.

23. Mondy, Wayne. (2016). Manajemen Sumber Daya Manusia Jakarta: Erlangga.

24. Muhammad Ramzan MBA Hafiz M Kashif Zubair MBA Ghazanbar Ali,MBA Muhammad Arslan, MBA (2014), Impact of compensation on employee Performance (Empirical evidence from banking sector of Pakistan), International Journal of Business and Social Science, Vol 5 No 2.

25. Nazir, M. (2014), Metode Penelitian. Jakarta, Ghalia Indonesia.

26. Ni Putu Diah Prawisanti, Ni Ketut Sariyathi (2018) Pengaruh Kompensasi Finansial, Stres Kerja, Dan Komitmen Organisasional Terhadap Niat Keluar Karyawan Hardy's Mallsdi Gianyar E-Jurnal Manajemen Unud, Vol. 7, No. 1, 134-163.

27. Nuria Erisna (2018), Pengaruh Lingkungan Kerja Dan Stres Kerja Terhadap Kinerja Karyawan Pada PT Golden Comucation TDC (Telkomsel Distrbution Center). Universitas Bandar Lampung.

28. Panggabean, M.S. (2014). Manajemen Sumber Daya Manusia. Bogor: Ghalia Indonesia.

29. Rivai, V and Sagala J.E, (2016). Manajemen Sumber Daya Manusia Untuk Perusahaan Dari Teori ke Parktik, PT. Rajawali Pers, Jakarta.

30. Rivai, V. (2014), Manajemen Sumber Daya Manusia Untuk Perusahaan, Jakarta: PT, Raja Grafindo Persada.

31. Rivai, V and Mulyadi. (2014). Kepemimpinan dan Prilaku Organisasi. Jakarta: PT. Rajagrafindo Persada.

32. Robbins, S. \& Coulter, M. (2016). Management. Prentice Hall. New Jersey.

33. Robbins, S. (2015). Perilaku Organisasi. Jakarta: Salemba Empat.

34. Rocky Potale and Yantje Uhing (2015) Pengaruh Kompensasi Dan Stres Kerja Terhadap Kepuasan Kerja Karyawan Pada Pt. Bank Sulut Cabang Utama Manado. Jurnal EMBA, Vol.3 No.1.

35. Samsuddin, S, (2014), Manajemen Sumber Daya Manusia. Bandung: Pustaka Setia.

36. Sedarmayanti. (2017). Manajemen Sumber Daya Manusia. Bandung: Refika Aditama.

37. Setiyana, V.Y. (2013) Forgiveness dan Stres Kerja Terhadap Perawat. Jurnal Ilmiah Psikologi Terapan. 1(2), 376-396.

38. Simamora, H. (2016). Manajemen Sumber Daya Manusia. Yogyakarta: Bagian Penerbitan Sekolah Tinggi Ilmu Ekonomi YKPN.

39. Sinambela. L. P. (2016). Manajemen Sumber Daya Manusia: Membangun Tim Kerja yang Solid untuk Meningkatkan Kinerja, Jakarta: Bumi Aksara.

40. Sitepu, N. and Meiditia 2015. Analisis Korelasi \& Regresi. Bandung: Unit Pelayanan Statistika jurusan Statistika, FMIPA, Universitas Padjajaran.

41. Stephen P. Robbins and Timothy A. Judge. (2015). Perilaku Organisasi. Terjemahan: Diana Angelica, Ria Cahyani and Abdul Rosyid. Jakarta: Salemba Empat.

42. Sudjana, (2014), Statistik Untuk Ekonomi dan Niaga, Bandung: Tarsito.

43. Sugiyono. (2017). Metode Penelitian Kuantitatif, Kualitatif, dan R\&D. Bandung: Alfabeta.

44. Sutrisno. E (2015). Manajemen Sumber Daya Manusia. Jakarta: Prenadamedia Group.

45. Suwatno and Donni Juni Priansa (2014), Manajemen SDM dalam Organisasi Publik dan Bisnis, Penerbit Bandung.

46. Umar, H (2014), Riset Sumber Daya Manusia. PT Gramedia Pustaka Utama, Jakarta.

47. Wahjono, Sentot Imam. (2013). Perilaku Organisasi Sentot Imam Wahjono. Yogyakarta: Graha Ilma.

48. Zulganef. (2013). Metode Penelitian Sosial \& Bisnis, Cet II. Yogyakarta: Graha Ilmu. 